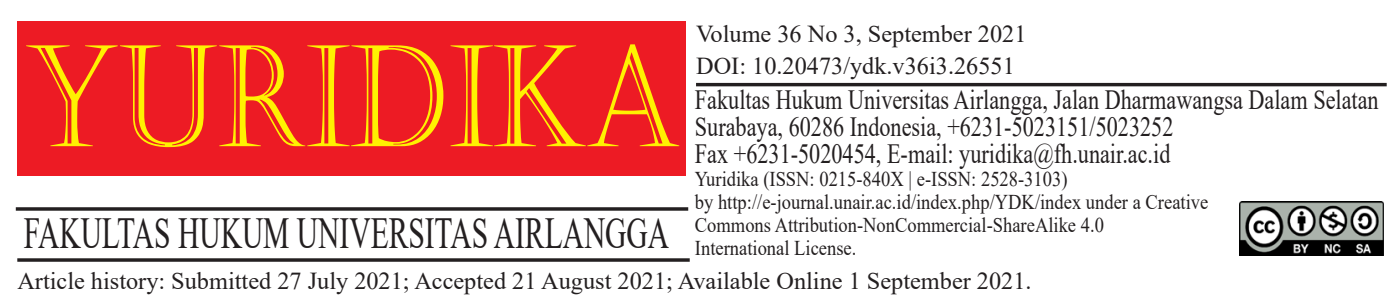

\title{
Reformulation of Regulation Concerning Share Ownership in Regional Development Banks by Regional Governments of Indonesia
}

\author{
Dien Nufitasari and Reka Dewantara \\ dienmine101010@gmail.com \\ Universitas Brawijaya
}

\begin{abstract}
Regional development banks (BPDs) are a realisation of regional governments' commitment to carry out the objectives of the Banking Law to improve the area. BPDs have an important role in moving the regional economies, but regulatory obstacles arise when norms conflict in terms of regulating share ownership by regions. Therefore, synchronisation is needed to realise legal certainty. This article aims to suggest reformulations to the regulation of share ownership of BPDs to give legal certainty. The article adopts a normative juridical law research method with statutory, conceptual and analytical approaches. The results of the study indicate there are inconsistencies in the provisions governing the share ownership of BPDs. There are juridical implications for the emergence of rights, obligations and legal relations due to inconsistent arrangements. Regulatory reformulation of BPD share ownership by regional governments should be carried out by adopting the concept of norms, resulting in consistent regulation.
\end{abstract}

Keywords: Reformulation; Share Ownership; Regional Development Banks.

\section{Introduction}

Regional-owned enterprises (ROEs) are one of the development pillars based on the 1945 Constitution, along with private-owned enterprises and unions. Article 54 of Act No 7/1992 concerning Banking as amended by Act No 10/1998 ('Banking Law') stipulates that with its enactment, the law concerning regional development banks (BPDs) is declared to remain valid for a maximum of one year from the entry into force of the Banking Law, ${ }^{1}$ provided that within one year, banks established under the BPD Act comply with the provisions of the Banking Law.

\footnotetext{
${ }^{1}$ Act No 7/1992 concerning Banking as amended by Act No 10/1998 art 54.
} 
This law provides the basis for the legality of BPDs. ${ }^{2}$ BPDs are regional financial institutions that use regional budgets and must be directed to create jobs (ie reduce unemployment), avoid the waste of resources, and increase the efficiency and effectiveness of the economy. ${ }^{3}$

BPDs are a manifestation and embodiment of regional governments' commitment to fulfilling the objective of the Constitution in improving the regional economic level. Article 2 of the Domestic Affairs Minister Regulation No 62/1999 regarding Organisation Guidelines and Working Procedure of Regional Development Bank states that the primary duty of BPDs is to develop the regional economy and encourage regional development through banking activities. Article 3 of the same regulation states that BPDs, as part of their primary duties, will be the driving force of economic development and regional development in improving the economic level of citizens, act as the regional cash holder or regional cash saver, and be a source of regional original income (ROI).

Government Regulation No 54/2017 regarding Regional-Owned Enterprises states that ROEs are meant to benefit the regional economic development, implement the main benefit and obtain profit. An ROE is established based on the region's needs and the appropriateness of the enterprise. The regulation also states there are two forms of ROE: the regional commercial company and the regional association company. The regional commercial company is an ROE whose capital is owned by one region and not divided by share. The regional association company is a company whose capital is divided by share, with all or at least $51 \%$ owned by one region.

Otoritas Jasa Keuangan (Indonesia Financial Services Authority; FSA) has the authority to stipulate regulations related to sustainable finance as part of its duties and functions in implementing banking arrangements. Sustainable finance is one of the activities required for all financial service industries, including the

\footnotetext{
${ }^{2}$ Gunawan Widjaja, ‘Status Hukum Bank Pembangunan Daerah' (2016) 2 Selisik.[29-30].

${ }^{3}$ Hardyanto, 'Tinjauan Hukum Tentang Kedudukan Gubernur Sebagai Pendiri Dan Pemegang Saham PT. Bank Sulteng’ (2014) 2 Jurnal Ilmu Hukum Legal Opinion.
} 
banking sector. ${ }^{4}$ Share ownership for banks is based on FSA regulations (POJK). One feature of a healthy and efficient banking system is that a bank can take care of the interests of its customers and the country. BPDs currently have the legal status of an open PT, and some are not public. Shareholders invest capital in a limited liability company, meaning the capital invested in the participation is separate from the shareholder's assets..$^{5}$ The regulation of this ROE is similar to state-owned enterprises (SOEs). In the case of an association company, all or at least $51 \%$ of its capital is owned by one region, meaning more than one region can own it.

Government regulations overlap with FSA regulations, and BPDs, as an ROE in banking, must obey both. For instance, ROE share ownership is based on Government Regulation No 54/2017, which provides that an ROE must have all or at least 51\% owned by one region. Based on this regulation, ROEs with all or a $51 \%$ share of capital ownership have not fulfilled the requirement of a state association company. FSA Regulation No 56/PJOK 03/2016 regarding Commercial Bank Ownership provides that the maximum limit of share ownership by a bank in every category of shareholders is as follows: (a) 40\% of the whole capital for a legal banking entity of a financial institution and a non-banking entity of a financial institution; (b) $30 \%$ of the whole capital for a non-financial legal entity; and (c) $20 \%$ for the association company. Thus, this FSA Regulation permits bank share ownership up to $30 \%$ for a non-financial institution and $40 \%$ for a banking financial institution. In contrast, the Government Regulation requires a region to own all or at least $51 \%$.

The main point regarding share ownership for banking is the overlapping government regulations and FSA regulations. It is also important to find the right formulation of BPD shareholders, mainly for the regional governments. With the right formulation, the overlapping regulation and interests of BPDs and other shareholders of non-regional governments can be avoided.

\footnotetext{
${ }^{4}$ Reka Dewantara and Bimarceline Agatha, 'Concretisation of the Principle of Sustainable Finance in the Banking Sector Legislation in Indonesia: Lon Fuller Eight Desiderata Approach' (2019) 5 Veritas et justicia.[249].

${ }^{5}$ Rudhi Prasetya, Kedudukan Mandiri Perseroan Terbatas (Citra Aditya Bakti 1996).[12].
} 
Aside from the overlapping of these regulations, it is important to study and explore the legal status of BPDs, which are also categorised as association companies. The reformulation of legal arrangements related to the share ownership of BPDs is needed to establish BPDs as the main driving force of regional economies. On the other hand, many legal regulations obstruct BPDs from further development.

Based on these abovementioned legal issues, the authors formulated three research questions to design this study:

(1).How is the regulation of share ownership of BPDs in Indonesia inconsistent?

(2). What are the juridical implications of the inconsistent regulation of share ownership of BPDs by regional governments in Indonesia?

(3). How does the reformulation of the regulation of share ownership of BPDs by the regional government in Indonesia give legal certainty?

\section{Inconsistent Regulation of Share Ownership of Regional Development Banks by the Regional Governments}

The assets of a BPD are the assets of the limited liability company. The assets of a limited liability company consist of (1) assets belonging to the limited liability company located on the left side of the balance sheet and (2) debts or obligations that must be repaid, including to shareholders, located on the right side of the balance sheet. Banking regulations require that banks do not use their own capital to carry out activities but instead use third-party funds in the form of deposits (ie demand deposits, time deposits, certificates of deposit, savings and/ or other equivalent forms). ${ }^{6}$ A BPD is obliged to maintain health, including its capital ownership by local governments. For this reason, capital ownership requires consistent arrangements with legal certainty.

1. Juridical Analysis of Act No 7/1992 and Regulation No 10/1998 Regarding Banking from the Perspective of Legal Certainty Theory

The Banking Law provides a fundamental legal umbrella for the banking

${ }^{6}$ Widjaja (n 2).[33]. 
industry in Indonesia. From an ownership perspective, a bank owner is whoever owns the bank. Ownership can be ascertained from the establishment document and control of the shares owned by the bank. A regional government bank is a regional government-owned bank located in the first-level and second-level regions of each province, such as Regional Government Bank of DKI Jakarta, Regional Government Bank of West Java, Regional Government Bank of Special Region of Yogyakarta, Regional Development Bank of Central Java and Regional Government Bank of East Java. Article 54 of the Banking Law states that with the enactment of the law, the Regional Government Bank Law is declared applicable for a maximum of one year after the Banking Law is effective. In accordance with the regulation, a bank established under the Regional Government Bank Law must adjust to the regulation under the Banking Law within one year. If the BPD has adjusted to the regulation under the Banking Law before the one year, then the Regional Development Bank Law no longer applies.

2. Juridical Analysis of Law No 19/2003 Regarding State-Owned Enterprises from the Perspective of Stufenbau Theory

According to Stufenbau theory, the constitution is the basic law that lays the foundation for a country's administration. Law No 19/2003 concerning State-Owned Enterprises states that SOEs have an important role in helping the national economy achieve societal welfare. The State-Owned Enterprise Law, built upon the foundation of the Constitution, regulates SOEs based on economic democracy.

An association company, in this case, is a regional government bank whose capital is divided into shares of which one region owns all or at least $51 \%$. This means more than one region can own an association company. The share ownership is based on the capital participation of regional governments, as set forth in the company's basic budget and stipulated by regional regulation. There is a similar binding condition for ROEs in article 1 paragraph (2) of Law No 19/2003 concerning State-Owned Enterprises, which states that association 
companies are SOEs in the form of incorporated companies whose capital is divided of which all or at least $51 \%$ shall be owned by the Republic of Indonesia whose main purpose is profit.

3. Juridical Analysis of Law No 40/2007 Regarding Incorporated Companies from the Perspective of Legal Certainty Theory

As Peter Mahmud Marzuki explains, legal certainty refers to understanding rules that inform individuals what acts may or may not be done. ${ }^{7}$ The general principle of Law No 40/2007 concerning Incorporated Companies (LPC Law) states that an incorporated company is a legal entity whose capital is separate from the shareholders, directors and commissioners. As such, the obligation of the BPD as a legal entity is the BPD's responsibility and is not the province's responsibility as the shareholder.

As an incorporated company, BPD assets are the assets of the incorporated company. The source of the BPD's capital is the capital deposit from the regional government and the provincial regional government, the regional government of the regency or the regional government of the city. ${ }^{8}$

4. Juridical Analysis of the Law No 23/2014 and Law No 9/2015 Regarding Regional Government from the Perspective of Authority Theory

Studies on BPDs should first review the profile of the province as an autonomous region, as regulated in Law No 23/2014 concerning Regional Government ('Local Government Law') amended by Law No 9/2015 concerning Regional Government. The provincial government is a legal subject, and the governor is the legal actor. Regional autonomy is the regional government's right, authority, and duty to regulate and manage the governance affairs and local social interests in the unity of the Republic of Indonesia system (see article 1 number 6 of the Local Government Law). Meanwhile, autonomous regions are united by law and territorial boundaries authorised to regulate and administer governance

\footnotetext{
${ }^{7}$ Peter Mahmud Marzuki, Pengantar Ilmu Hukum (Kencana Pranada Media Group 2008). [158].

${ }^{8}$ Widjaja (n 2).[35].
} 
affairs and local government interests according to local government initiatives based on the people's aspirations (see article 1 of the Regional Government Law). The autonomous region is led by the regional government, divided into governors for the provinces and mayors for the second-level regions.

The legal arrangement of regional financial management using the instruments of decentralisation, deconcentration and co-administration should encourage the regions to improve their service functions without exploiting ROI resources or exceeding the normal/capability limits of the people. Structuring financial relations between the central and the regional governments and developing the principles of good governance based on local wisdom are strategic steps in implementing regional autonomy. ${ }^{9}$

5. Juridical Analysis of Government Regulation No 54/2017 Regarding RegionalOwned Enterprises from the Perspective of Stufenbau Theory

Law No 23/2014 concerning Regional Government mandates the preparation of government regulations on ROE. With the revocation of Law No 5/1962 concerning Regional Enterprises after the promulgation of Law No 23/2014 concerning Regional Government, government regulations need to be formulated to fill the legal vacuum of regulations on ROE.

Stufenbau theory states that the legal system is a ladder system with hierarchical steps, where the lowest legal norms must uphold the higher legal norms, and the highest legal norms (eg the constitution) must uphold the most fundamental legal norms (ground norm). Government Regulation No 54/2017 concerning Regional-Owned Enterprise aims to implement the regulations of the 1945 Constitution of the Republic of Indonesia and the Regional Government Law. BPD is a form of a legal entity of regional association companies. The Government Regulation regarding RegionalOwned Enterprise provides as follows:

\footnotetext{
${ }^{9}$ Riawan Tjandra, Hukum Keuangan Negara (Penerbit PT Grasindo 2014).[198].
} 
Article 5 Paragraph (2)

Regional Association Companies are Regional-owned Enterprise in the form of Incorporated whose capital divided in the share where the whole shares or at least $51 \%$ of its share is owned by 1 (one) region.

6. Juridical Analysis of FSA Regulation No 56/PJOK/2016 Regarding the Share Ownership of Commercial Bank from the Perspective of Authority Theory

On 31 December 2012, the FSA started overseeing the functions, duties, and authority of regulating and supervising non-bank financial service activities such as the capital market, insurance, pension funds, financing institutions and otherfinancial institutions. One year later(31 December 2013), the same transition was made from Bank Indonesia (BI) to the FSA in regulating and supervising financial service activities in the banking sector. With the effectiveness of Law No 21/2011, the FSA conducts all supervision activities related to financial services for bank financial services and non-bank services. Philipus M Hadjon used authority theory to divide the method of obtaining authority into two ways: (1) attribution and delegation and (2) mandate. The legislators appointed FSA as the manifestation of the theory, especially delegations.

Based on the provisions of FSA Regulation No 56/POJK.03/2016 concerning the share ownership of Commercial Bank, the share ownership limit for banks in each shareholder category is $40 \%$ of bank capital for shareholders in the form of a legal entity of bank as financial institutions and non-bank financial institutions.

7. Juridical Analysis of Regulation of BI No 14/2012 Regarding Share ownership of Commercial Bank from the Perspective of Legal Certainty Theory

Chapter II of the Regulation of BI No 14/2012 regarding the share ownership of commercial banks provides the maximum limit of share ownership as follows:

Article 2 Paragraph (2)

The maximum limit of share ownership of bank in every category of shareholders is determined as follow: ' $40 \%$ (forty percent) of the whole bank capital, for category of shareholder in the form of legal entity financial institution and non-bank financial institution.' 
As provided in this regulation, there are special requirements for shareholders who want to own shares exceeding the limit. By regulating the requirements for shareholders who wish to own more than the maximum ownership limit as regulated in articles 2 and 4 of the Regulation of BI No 14/2012, shareholders must have a good level of good corporate governance.

8. Juridical Analysis of the Regulation of Domestic Affairs Minister No 13/2006 Regarding Guidelines of Regional Financial Management from the Perspective of Authority Theory

Capital participation by the regional government - in this case, the first level of the regional governor - separates part of the wealth or funds, which are then included as shares in the BPD. This capital investment cannot be withdrawn. Thus, the provincial funds used as capital in the form of BPD shares legally change their status, becoming the property of the BPD. For that reason, the province is only entitled to receive profit from the capital investment of the BPD, as affirmed by article 26 (3) letter c of the Regulation of Domestic Affair Minister No 13/2006. According to article 16 paragraph (4) of the same regulation, the allocation made in article 13 paragraph (3) implies that the regional budget must be directed to create jobs, reduce unemployment, reduce the waste of resources, and increase the efficiency and effectiveness of the economy. The capital participation by the first level of the regional government to the BPD is set forth in the regional regulation regarding capital participation by the first and second levels of regional governments. ${ }^{10}$

\section{Juridical Implication of Inconsistent Regulations Regarding Share Ownership of Regional Development Banks by the Regional Governments in Indonesia}

1. Rights Resulting from Inconsistent Regulations Regarding the Share Ownership of Regional Development Banks by Regional Governments in Indonesia Inconsistency over which regulations BPD should obey has impacted

\footnotetext{
${ }^{10}$ Hardyanto (n 3).
} 
BPD. The rights that exist as the result of the inconsistent regulations regarding the share ownership of BPD can be explained as follows:

a. As the controlling shareholder with $25 \%$ of share ownership of the BPD, the regional government has the right to own, manage, monitor and/or significantly influence the performance report of the BPD and significant responsibility to maintain the well-being of the BPD.

b. In some remote provinces, regional governments have almost $100 \%$ ownership, which will significantly influence the performance of BPDs as every business decision will depend on the political policy of the local government and will affect the well-being of the BPD.

c. Reformulating legal regulation of BPD share ownership by the local government is an example of efforts in avoiding the rule of interpretation practice (which varies from person to person and is attached to interest) as justification for unfounded discretionary practices. If the government adheres to the Government Regulation regarding Regional Development Bank and the State-Owned Enterprise Law and capital ownership remains close to $100 \%$, the practice of discretion by the regional government will grow, resulting in the poor development of BPDs due to political interests.

2. Obligations Resulting from Inconsistent Regulations Regarding the Share Ownership of Regional Development Banks by the Regional Governments in Indonesia

Obligations arising from the inconsistent regulation of ROEs encourage the need for a legal basis to manage ROEs. As such, ROEs are considered unable to conduct good work ethics, too bureaucratic and inefficient. They are also considered to lack market orientation, good reputation and professionalism. Moreover, too many interventions from regional governments and unclear objectives between profit and social function can result in a lack of main vision.

Other obligations arising from the inconsistent regulations regarding the share ownership of BPD by regional governments are maintaining the wellbeing of BPDs. The inconsistent regulations obligating regional governments 
to intervene as controlling shareholders in ROEs result in legal uncertainty for capital participation in BPDs. Whether or not it needs to be stated in the form of local regulations or the approval of the local Regional Representative Council is enough with legal considerations of the regulation that exist in Government Regulation regarding Regional-Owned Enterprise or FSA Regulation.

3. Legal Relations Emerging from Inconsistent Regulations Regarding the Share Ownership of Regional Development Banks by Regional Governments in Indonesia

BPDs are different from ROEs. They have their own assets sourced from the regional government (both the province as the first level of government and the regency/city as the second level of government) whose ownership has been transferred from the regional government to the BPD. BPDs follow the Banking Law rather than the Local Government Law because they conduct the functions of a bank. Since the release of Law No 21/2011 concerning the Financial Services Authority, the FSA has conducted all supervision related to financial services, both for bank financial services and non-bank services. In accordance with the lex specialis derogat legi generali principle, FSA Regulation No 56/POJK.03/2016 is a legal reformulation that rightly regulates the regional government ownership of BPDs and limits it to $40 \%$.

As the controlling shareholder with $25 \%$ of share ownership of the $\mathrm{BPD}$, the regional government has the right to own, manage, monitor and/ or significantly influence the performance report of the BPD and significant responsibility to maintain the well-being of the BPD. Moreover, in some remote provinces, regional governments have almost 100\% ownership, which will significantly influence the performance of BPDs as every business decision will depend on the political policy of the local government and will affect the wellbeing of the BPD.

Reformulating legal regulation of BPD share ownership by the local government is an example of efforts in avoiding the rule of interpretation practice (which varies from person to person and is attached to interest) as 
justification for unfounded discretionary practices. If the government adheres to the Government Regulation regarding Regional Development Bank and the State-Owned Enterprise Law and capital ownership remains close to $100 \%$, the practice of discretion by the regional government will grow, resulting in the poor development of BPDs due to political interests.

\section{Reformulation of Legal Regulation Regarding Share Ownership of Regional} Development Banks by Regional Government in Indonesia which Require Legal Certainty

The role of the BPD for regional community development is still needed, especially for local governments throughout Indonesia. Law No 13s/1962 concerning the Basic Regulations of Regional Development Banks provides an important role in the framework of regional development, especially as a driving force of the regional economy. Furthermore, the enactment of Law No 7/1992 and Law No 10/1998 concerning Banking led to the abolishment of the Regional Development Banking Law. ${ }^{11}$

Article 54 of the Banking Law states that with the enactment of the law, the Regional Development Bank Law is effective for one year. After that, in accordance with the regulation, a bank established under the Regional Development Bank Law must adjust to the regulation under the Banking Law. If the BPD has adjusted to the regulation under the Banking Law before one, then the Regional Development Bank Law no longer applies.

In accordance with the Banking Law, BI regulates and determines the share ownership of banks as an inseparable part of the requirements for the establishment of banks and legal entities that wish to hold shares in commercial banks. To avoid a dominance of share ownership resulting in an adverse impact on operations, BI issued Regulation No 8/14/2012 about Share Ownership of Commercial Banks. BI's regulation is meant to increase public trust in banking institutions - in this

${ }^{11}$ Widjaja (n 2). 
case, commercial banks - by increasing the good corporate governance of related banks. $^{12}$

On 31 December 2012, the FSA started overseeing the function, duties and authority of regulating and supervising non-bank financial service activities, such as market share, insurance, pension funds, funding institutions and other financial institutions. A year later, on 31 December 2013, the same transition was made from BI to FSA in regulating and supervising the financial service activities in the banking sector. With the establishment of Law No 21/2011, the FSA conducts all supervision activities related to financial services for banks or non-banks.

Considerations of FSA Regulation No 56/POJK.03/2016 concerning Share Ownership of Commercial Bank states:

c. whereas to enhance the implementation of the principles of prudence and governance, it is necessary to restructure the share ownership structure of bank; d. whereas the structuring of the share ownership structure of bank is conducted through the application of the maximum limit of share ownership so as to reduce the dominance of ownership which can negatively impact bank operations; e. that the application of the maximum limit of share ownership will also have a positive impact in encouraging consolidation of banking in strengthening the sustainable of national banking industry.

These considerations underscore the urgency of the regulation limiting the share ownership of commercial banks.

Capital participation by the regional government - in this case, the first level of regional governor - separates part of the government's wealth or funds, which are then included as shares in the BPD. This capital investment cannot be withdrawn. Thus, the provincial government funds used as capital BPD's shares legally change their status, becoming the capital of BPD. For that reason, the provincial government is only entitled to receive profit from the capital investment on the BPD, as affirmed by article 26 (3) letter c of the Regulation of Domestic Affairs Minister No 13/2006. According to article 16 paragraph (4) of this regulation, the allocation referred by article 13 paragraph (3) implies that the regional budget must be directed to create

${ }^{12}$ Siti Zubaedah, 'Tinjauan Yuridis Peraturan Bank Indonesia Nomor: 14/8/PBI/2012 Tentang Kepemilikan Saham Bank Umum’ (2013). 
jobs, reduce unemployment, reduce the waste of resources, and improve economic efficiency and effectiveness. ${ }^{13}$

According to article 2 of the Minister of Domestic Affairs Regulation 1-98, the legal form of the BPD can be a regional company or incorporated company. Article 3 of the same regulation further states that the BPD, whose legal form is a regional company, is subject to the prevailing laws and regulations governing the regional company. The Regional Company Law was effective then. However, the Local Government Law has replaced 'regional company' with ROE. If the BPD is legally incorporated as an incorporated company, it is subject to Law No 1/1995 concerning Incorporated Companies and its implementing regulations. At present, Law No 1/1995 has been replaced by Law No 40/2007 concerning Incorporated Companies (State Gazette of the Republic of Indonesia No 106/2007, Supplement to the State Gazette of the Republic of Indonesia No 4756). In accordance with Law No 40-07, if an incorporated company is a legal entity with a capital alliance, established based on an agreement, conducts business activities with authorised capital entirely divided into shares and meets the requirements of Law No 40/2007 and its implementing regulations, then all rules relating to BPD as an association company are subject to Law PT-07.14

An association company is a BPD whose capital is divided into shares, of which all or at least $51 \%$ are owned by one region. More than one region can own this association company. Share ownership is through local government capital participation, as stated in the company's articles of association and stipulated by regional regulation. Article 1 paragraph (2) of Law No 19/2003 concerning StateOwned Enterprises provides the same binding conditions on ROEs: association companies are SOEs in the form of incorporated companies with their capital divided into shares of which all or at least $51 \%$ are owned by the Republic of Indonesia whose main purpose is to pursue profits.

Regarding the legal entity form of ROEs, both the Regional Government Law and Government Regulation No 54/2017 concerning Regionally Owned

\footnotetext{
${ }^{13}$ Hardyanto (n 3).

${ }^{14}$ Widjaja (n 2).[34].
} 
Enterprises implies guidelines for ROEs that existed prior to the Local Government Law. Pursuant to the Regulations for Regional Development Bank as a Regional Company, if a regional public company is owned by more than one region, the regional public company must change the legal form to a regional company (article 334 paragraph (2) of the Regional Government Law). The position of the regional company as a legal entity is obtained in accordance with the provisions of the law governing incorporated companies (article 339 paragraph (2) of the Regional Government Law in conjunction with article 4 paragraph (5) and article 136 of the Government Regulation regarding Regionally Owned Enterprises).

Government Regulation No 54/2017 concerning Regionally Owned Enterprises has a story that Law No 5/1962 concerning Regional Enterprises was revoked and replaced by Law No 23/2014 concerning Regional Government. As a result, regional companies are regulated by new government regulations and are now called ROEs. A regional government owns all or most of the shares of ROEs. ROEs were established to benefit regional economic development in general, organising public benefits in the form of providing good quality goods and/or services to fulfil people's lives according to the conditions, characteristics and potential of the area based on good corporate governance.

Based on the description above, there are differences in the portion of share ownership in BPD. Law No 19/2003 concerning State-Owned Enterprise and Government Regulation No 54/2017 concerning Regional-Owned Enterprise requires that the company is an SOE in the form of an incorporated company whose capital is divided into shares of which are all or at least $51 \%$ of the shares is owned by the Republic of Indonesia, whose main purpose is to pursue profit. This regulation is similar to article 5 paragraph (2) of Government Regulation No 54/2017, which states that an ROE is an incorporated company whose capital is divided into shares that are wholly or at least $51 \%$ owned by one region.

BI Regulation No 14/8/2012 concerning Commercial Bank Share Ownership and FSA Regulation No 56/POJK.03/2016 concerning Commercial Bank Share Ownership strengthened Banking Law No 7/1992 and Law No 10/1998. The share 
ownership limit for banks in each shareholder category is $40 \%$ of bank capital for shareholders in the form of a legal entity of banks as financial institutions and nonbank financial institutions.

According to Apeldoorn, the legal standing has two facets. The first concerns the establishment of law in concrete matters. Those who seek justice want to be in the law in special matters before the case starts. The second concerns the certainty of law, meaning the safety of law, and the protection of many parties against the arbitrariness of the judiciary. The certainty of the law can be used to measure the truth and achieve the objectives of the law - peace, safety, welfare and order. The certainty of the law must guarantee public welfare and justice for the people. The theory of legal certainty reinforces the need for the limitation of share ownership in BPDs by regional governments to eliminate differences in perception for all local governments due to the overlap of existing legal regulations.

The authors believe that reformulating the regulations of BPD share ownership by the regional government is important. BPDs are ROEs subject to Law No 40/2007, the Government Regulation regarding Regional-Owned Enterprise, the Banking Law, Regulation of BI and FSA Regulation. They should be given legal certainty to operate and achieve rapid development of their objectives as the driving force of the regional economy and a source of ROI.

Han Kelsen's Stufenbau theory states that the legal system is a ladder system with a hierarchical rule, where the lowest legal norms must uphold the higher legal norms, and the highest legal norms (eg the constitution) must uphold the most basic legal norms (ground norm). Government Regulation of Regional-Owned Enterprise was based on the regulations contained in the Regional Government Law as a manifestation of the 1945 Constitution, which regulates economic justice and regional autonomy. Article 5 paragraph (2) of the same regulation states that a regionally owned company is an ROE in the form of an incorporated company whose capital is divided into shares with all or at least $51 \%$ owned by one region and can be replaced with at least $40 \%$ of the shares owned by one region. This is meant to eliminate the inconsistency and confusion for both BPDs in developing 
their capital and regional governments throughout Indonesia as main shareholders. The limitation of BPD share ownership by the local governments is hoped to reduce the practice of discretion so that the development of BPDs will no longer be laden with politics.

\section{Implications of the Policy}

The type of bank seen from the ownership perspective can also be seen from the certificate of establishment and control of shares ownership. BPDs are owned by regional governments located in the first and second regional levels of each province. However, there are inconsistencies in the provisions governing share ownership of BPDs by regional governments in terms of legal certainty theory, authority theory and Stufenbau theory, as follows:

1. Law No 7/1992 and Law No 10/1998 Regarding Banking.

2. Law No 19/2003 regarding State-Owned Enterprise.

3. Law No 40/2007 regarding Incorporated Company.

4. Law No 23/2014 and Law No 9/2015 regarding Regional Government.

5. Government Regulation No 54/2017 regarding Regional-Owned Enterprise.

6. FSA Regulation No 56/PJOK.03/ 2016 regarding Share Ownership of Commercial Bank.

7. Regulation of BI No 14/2012 regarding Share Ownership of Commercial Bank.

8. Regulation of Domestic Affairs Minister No 13/2006 regarding Guidelines for the Regional Financial Management.

The inconsistency over which regulations BPDs should use adversely impacts them.

1. The emerging rights due to inconsistent regulation regarding the share ownership of BPDs by regional governments in Indonesia are as follows:

a. As the controlling shareholder with $25 \%$ of share ownership of the BPD, the regional government has the right to own, manage, monitor and/or significantly influence the performance report of the BPD and significant responsibility to maintain the well-being of the BPD.

b. In some remote provinces, regional governments have almost $100 \%$ ownership, which will significantly influence the performance of BPDs as every business decision will depend on the political policy of the local 
government and will affect the well-being of the BPD.

c. Reformulating legal regulation of BPD share ownership by the local government is an example of efforts in avoiding the rule of interpretation practice (which varies from person to person and is attached to interest) as justification for unfounded discretionary practices. If the government adheres to the Government Regulation regarding Regional Development Bank and the State-Owned Enterprise Law and capital ownership remains close to $100 \%$, the practice of discretion by the regional government will grow, resulting in the poor development of BPDs due to political interests.

2. The emerging obligations due to inconsistent regulation regarding the share ownership of BPDs by regional governments in Indonesia are as follows:

a. Encouraging the establishment of a legal basis of ROE management, such as ROEs lack work ethics, have too much bureaucracy, are inefficient, lack market orientation, lack a good reputation and lack professionalism. Moreover, regional governments overly intervene in ROE policy. There are also unclear objectives between making profit and maintaining the social function, resulting in a lack of focus on the primary vision.

b. Another obligation emerging due to inconsistent regulation regarding the share ownership of BPDs by the regional governments is the obligation to maintain the bank's well-being. The lack of share ownership in BPD, whether by the local government or after the bank goes public, will influence its CAR and well-being. It should also be the primary focus of the policy makers to respond to the main juridical disharmony of the legal regulation regarding the share ownership of BPD by the local governments in Indonesia.

3. The emerging legal relationships due to inconsistent regulation regarding the share ownership of BPDs by regional governments in Indonesia are as follows:

a. The relationship between principles, norms and rules can be seen. If a conflict of rules occurs, it will be resolved by applying the principle as a meta rule. Samuel Meira Brasil, Jr states that in law argumentation theory, 
there is a difference between rules and principles. A conflict of rules is resolved by principles and meta rules, such as lex superior (based on the general hierarchy of the legal system structure), lex posterior (based on priority rules that apply later), lex specialist (based on rule specifications) and exceptions. For example, based on the principle of lex specialit derogae legi generali, the FSA Regulation provisions deviate from the Government Regulation provisions and the Regional Government Law because they are specific in accordance with the law.

b. The regional government, as the controlling shareholder with a portion of ownership of at least $25 \%$ of the BPD's capital, is legally entitled to own, manage, supervise and/or significantly influence the BPD's Performance Report. It is also responsible for maintaining the bank's well-being. For some BPDs in slightly remote provinces, the shares ownership is almost $100 \%$ owned by the local government, which affects the bank's performance because every business decision depends on the political policies of the local government. This will also impact the bank's well-being. Reformulating legal regulation of BPD share ownership by the local government is an example of efforts in avoiding the rule of interpretation practice (which varies from person to person and is attached to interest) as justification for unfounded discretionary practices. If the government adheres to the Government Regulation regarding Regional Development Bank and the State-Owned Enterprise Law and capital ownership remains close to $100 \%$, the practice of discretion by the regional government will grow, resulting in the poor development of BPDs due to political interests.

There are some portions of share ownerships in BPD. For example, Law No 19/2003 regarding State-owned Enterprise and Government Regulations No 54/2017 regarding Regional-Owned Enterprise requires the association company be an SOE in the form of incorporated company whose capital is divided into shares of which all or at least $51 \%$ are owned by the Republic of Indonesia with the main objective of gaining profit. This regulation is similar to article 5 paragraph (2) of 
Government Regulation No 54/2017, which states that the regional association company is a state-owned company in the form of incorporated company with all or at least $51 \%$ of its capital owned by one region.

BI Regulation No 14/8/2012 concerning Commercial Bank Share Ownership and FSA Regulation No 56/POJK.03/2016 concerning Commercial Bank Share Ownership strengthened Banking Law No 7/1992 and Law No 10/1998. The share ownership limit for banks in each shareholder category is $40 \%$ of bank capital for shareholders in the form of a legal entity of banks as financial institutions and nonbank financial institutions.

The authors believe that reformulating the regulations of BPD share ownership by the regional government is important. BPDs are ROEs subject to Law No 40/2007, the Government Regulation of Regional-Owned Enterprise, Banking Law, Regulation of BI and FSA Regulation. They should be given legal certainty to operate and flourish rapidly in their objectives as a driving force of the regional economy and a source of ROI. Article 5 paragraph (2) of the Government Regulation of Regional-Owned Enterprise states that the regionally owned company is an ROE in the form of an incorporated company whose capital is divided into shares with all or at least $51 \%$ owned by one region and can be replaced with at least $40 \%$ of their shares owned by one region. This arrangement is meant to avoid inconsistency and confusion in developing BPD capital and regional governments as shareholders. The limitation of BPD share ownership by the local governments is hoped to reduce the practice of discretion so that the development of BPDs will no longer be laden with politics. In addition, the bank's well-being is also well maintained, as explained previously.

The juridical implications of the inconsistent regulations regarding BPD shares ownership by regional governments adversely impact the banks. This results in rights, obligations and legal relations arising from inconsistent regulations. Answering the second problem statement, based on the principle of lex specialit derogae legi generali, meaning specific legal rules are considered valid in contrast to general legal rules. The FSA Regulation provisions deviate from the Government 
Regulations provisions and the Regional Government Law because they are more specific in accordance with the law.

Regulations regarding share ownership in BPDs by regional governments in Indonesia should be reformed to have legal certainty. BPDs are ROEs subject to Law No 40/2007, the Government Regulations of Regional-Owned Enterprise, Banking Law, the Regulation of BI and FSA Regulation. They should be given legal certainty to encourage the banks to rapidly grow to achieve the objective as the driving force of the regional economy and the source of ROI. Article 5 paragraph (2) of the Government Regulation of Regional-Owned Enterprise states that the regionally owned company is an ROE in the form of an incorporated company whose capital is divided into shares with all or at least $51 \%$ owned by one region and can be replaced with at least $40 \%$ of shares owned by one region. This is meant to avoid inconsistency and confusion for BPDs in developing their capital and regional governments throughout Indonesia as shareholders. Therefore, the limitation of BPD share ownership by the local governments is hoped to reduce the practice of discretion so that the development of BPDs will no longer be laden with politics. Thus, a common perception is needed for regional governments throughout Indonesia to regard the reformulation of legal arrangements of BPD share ownership by regional governments with legal certainty.

\section{Bibliography}

Act No 7/1992 concerning Banking as amended by Act No 10/1998.

Dewantara R and Agatha B, 'Concretisation of the Principle of Sustainable Finance in the Banking Sector Legislation in Indonesia: Lon Fuller Eight Desiderata Approach' (2019) 5 Veritas et justicia.

Hardyanto, 'Tinjauan Hukum Tentang Kedudukan Gubernur Sebagai Pendiri Dan Pemegang Saham PT. Bank Sulteng' (2014) 2 Jurnal Ilmu Hukum Legal Opinion.

Marzuki PM, Pengantar Ilmu Hukum (Kencana Pranada Media Group 2008).

Prasetya R, Kedudukan Mandiri Perseroan Terbatas (Citra Aditya Bakti 1996). 
Tjandra R, Hukum Keuangan Negara (Penerbit PT Grasindo 2014).

Widjaja W, ‘Status Hukum Bank Pembangunan Daerah’ (2016) 2 Selisik.

Zubaedah S, 'Tinjauan Yuridis Peraturan Bank Indonesia Nomor: 14/8/PBI/2012 Tentang Kepemilikan Saham Bank Umum’ (2013).

HOW TO CITE: Dien Nufitasari and Reka Dewantara, 'Reformulation of Regulation Concerning Share Ownership in Regional Development Banks by Regional Governments of Indonesia' (2021) 36 Yuridika. 